\title{
OUT-OF-PLANE COORDINATED ZIRCONIUM(IV) AND HAFNIUM(IV)
} PHTHALOCYANINATES

\section{V.Y. Chernii ${ }^{\star}$ I.M. Tretyakova ${ }^{1}$, L.A. Tomachynska ${ }^{1}$, Y.S. Gerasymchuk ${ }^{2}$, S.V. Chernii ${ }^{1}$, V.I. Pekhnyo ${ }^{1}$}

${ }^{1}$ V.I. Vernadskii Institute of General and Inorganic Chemistry of the National Academy of Sciences of Ukraine, 32/34 Akad. Palladina Ave., Kyiv, Ukraine

${ }^{2}$ Institute of LowTtemperatures and Structural Research of the Polish Academy of Sciences, st. Okolna 2, 50-422, Wroclaw, Poland

*e-mail:v.chernii@gmail.com

The article is devoted to methods of synthesis, the structure, and spectral characteristics of zirconium and hafnium phthalocyaninates with out-of-plane coordinated ligands. The general scheme for the synthesis of out-of-plane coordinated $\mathrm{Zr}$ and $\mathrm{Hf}$ phthalocyanines includes obtaining initial dichloride or dihydroxo complexes, which then undergo substitution reactions with $\beta$-dicarbonyl compounds, hydroxybenzoic, sulfo- and aliphatic carboxylic acids, etc. In the case of polyphenols, which are bidentate ligands, one ligand is coordinated to the central atom of the macrocycle. If $\beta$-dicarbonyl compounds or carboxylic acids are introduced into the reaction, two ligands are coordinated. The reactivity of the out-of-plane coordinated ligands of $\mathrm{Zr}$ and $\mathrm{Hf}$ phthalocyanines was also investigated. In all obtained out-of-plane coordinated $\mathrm{Zr}$ and $\mathrm{Hf}$ phthalocyanines, the ligands are located in the cis position relative to the plane of the phthalocyanine macrocycle. X-ray diffraction, NMR, and UV-Vis spectroscopy have proved this arrangement of ligands. According to the X-ray diffraction data of $\mathrm{Zr}$ and $\mathrm{Hf}$ dibenzoylmethanato phthalocyanines, the metal atom is out of the plane of the phthalocyanine macrocycle, which itself is not planar. The central atoms are located almost in the middle between the N4 planes of the phthalocyanine macrocycle and the O4 of the extraplanar ligands. The UV-Vis spectra of out-of-plane coordinated Zr and Hf phthalocyanines in organic solvents have a typical appearance for most metal phthalocyanines, characterized by a B-band of absorption in the region of 335-350 nm, a Q-band at 680-690 nm, and its satellite in the region of 615-620 nm. If the extraplanar ligand is a chromophore (e.g., curcumin or condensed derivatives of dehydroacetic acid), there are additional absorption bands in UV-Vis spectra located between the B- and Q-bands. The influence of the nature of the central metal atoms, ligands and solvents on the fluorescent properties of the out-of-plane coordinated $\mathrm{Zr}$ and $\mathrm{Hf}$ phthalocyanines was also discussed.

Keywords: phthalocyanines, zirconium, hafnium, synthesis, spectroscopy. 
INTRODUCTION. The phthalocyanine macrocycle was first obtained by chance in 1907 [1] and its copper salt in 1927 [2] as a by-product of reactions of phthalic acid derivatives. The new unknown substance attracted attention because it had deep blue color, was thermally stable, and did not decompose in alkalies and acids. In 1934, Linstead showed that phthalocyanines are formed at high temperatures from various phthalic acid derivatives via the stage of formation of 1,2-dicyanobenzene, and that phthalocyanine itself is its tetramer and may contain a metal ion [3]. The following year, Robertson confirmed the structure and aromaticity of the phthalocyanine macrocycle by X-ray diffraction [4]. Subsequently, Linstead developed general methods for the synthesis of various phthalocyanine precursors, in particular, o-dinitriles [5-8], metal phthalocyanines [9-13], substituted phthalocyanines $[14,15]$, and their analogues [16-23]. To date, complexes of phthalocyanines with most metals and some nonmetals have been described [24].

Phthalocyanines are aromatic systems wherein the number of $\pi$-electrons in the conjugate system corresponds to Huckel's rule $(4 n+2)$ and is 42 electrons. Their aromaticity is confirmed by the proximity of the bond lengths in the molecule: the bond length $(\mathrm{C}-\mathrm{N})$ in the macrocycle $(1.35 \AA)$ is close to the bond length in benzene nuclei (1.40 $\AA$ ). At the same time, the bond length (C-C) between the macrocycle and benzene rings is significantly longer; it is $1.50 \AA$, which is close to the length of the $\sigma$-bond $(1.54 \AA)$. This indicates that the coupling between the $\pi$-electron systems of the macrocycle and benzene nuclei is weak. Thus, there are two quasi-autonomous aromatic sys- tems of benzene nuclei and an aromatic macroring system in the molecule [25]. The $\pi$-electron system of the phthalocyanine molecule is quite large; the difference in the energy level of HOMO and LUMO corresponds to the photon energy of the long-wavelength part of the spectrum. This causes a deep blue or green color of these compounds.

The aromaticity of phthalocyanines explains their high thermal and chemical stability and low tendency to open the conjugate macrocycle system [24]. The phthalocyanine macrocycle, as an aromatic system, undergoes electrophilic substitution reactions: chlorination, bromination, sulfochlorination, sulfonation, etc. However, these reactions result in a nonstoichiometric mixture of different isomeric compounds. Therefore, appropriate substituted o-dinitriles are generally used to produce peripherally substituted phthalocyanines. Nevertheless, individual compounds are formed only from symmetric o-dinitriles (for example, 4,5- or 3,6-substituted 1,2-dicyanobenzenes). In all other cases, mixtures of isomeric products are formed.

Phthalocyanine ligand is a dibasic, tetradentate acid. The cavity diameter of the phthalocyanine macrocycle is $3.65-4.50 \AA$ [24], which is suitable for the coordination of most metal ions. If the valence of the metal ion in the phthalocyanine complex is more than two, or its coordination number is more than four, then such a central metal atom (CA) contains (or may contain) additional axial or out-of-plane ligands. In [24], some possible types of out-of-plane ligands coordinating to the phthalocyanine macrocycle are presented (Fig. 1). 

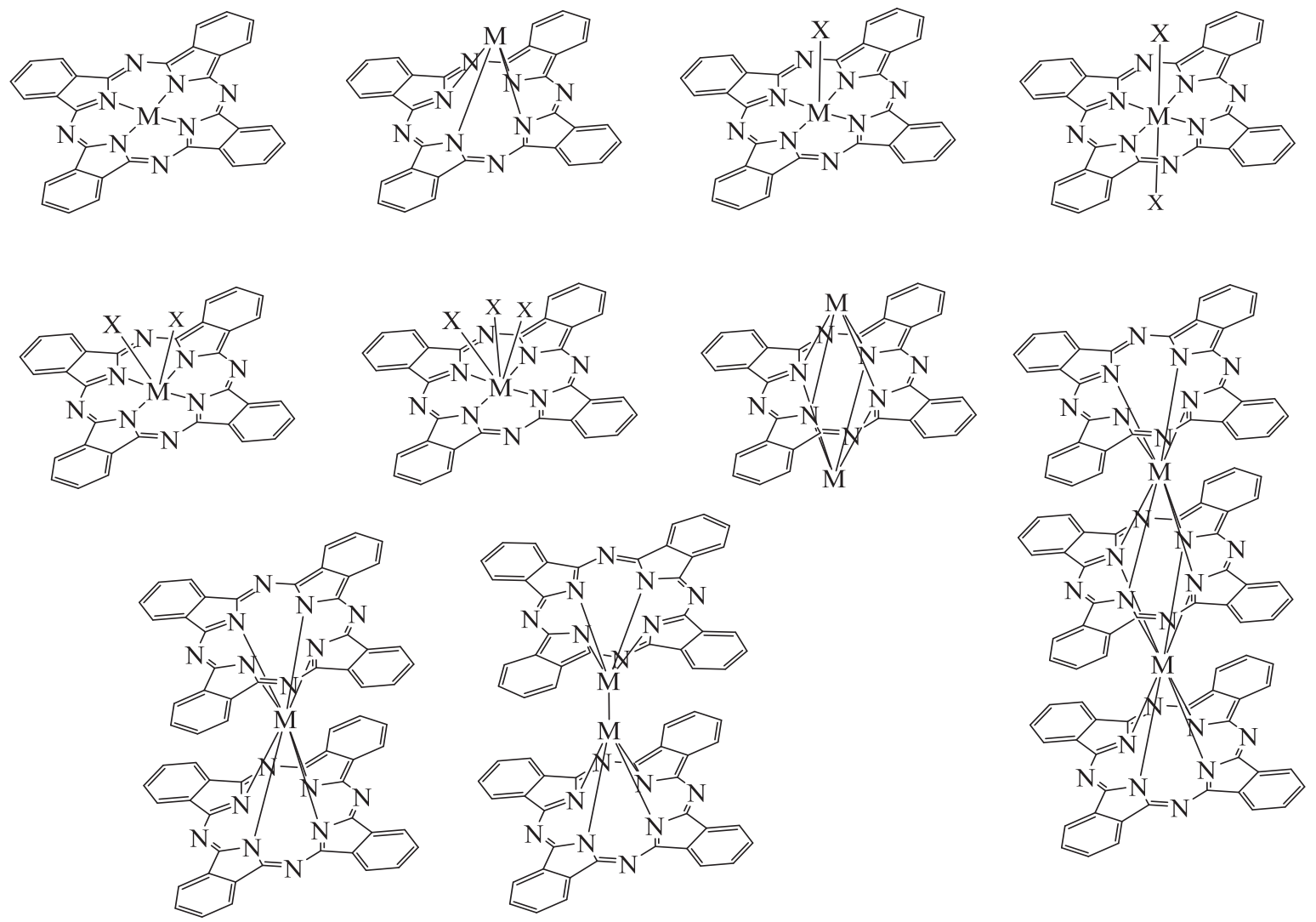

Fig. 1. Molecular structures of different types of phthalocyanine complexes $\mathrm{Pc}_{1} \mathrm{M}_{\mathrm{m}} \mathrm{X}_{\mathrm{n}}$ [24].

The high coordination numbers of the CA make it possible to form out-of-plane coordinated complexes of various compositions and structures. For example, carboxylate complexes are described for phthalocyanines of tin with coordination numbers $(\mathrm{CN}) 7$ or $8[26$, 27] and phthalocyanines of $\mathrm{Zr}$ and $\mathrm{Hf}$ with $\mathrm{CN} 8$, in which the carboxylate ligand can be bridged between two macrocyclic systems [28]. (Fig. 2). For phthalocyanines of $\mathrm{Zr}$ and $\mathrm{Hf}$, out-of-plane coordinated complexes with a reasonably wide range of ligands are described.

Methods of synthesis of zirconium and hafnium phthalocyaninates with out-of-plane coordinated ligands. $\mathrm{Zr}$ and $\mathrm{Hf}$ phthalocyanine dichloride complexes were first obtained by fusing 1,2-dicyanobenzene with the corresponding metal tetrachlorides [29]. However, it was found [30] that the reaction produces $\mathrm{Zr}$ and $\mathrm{Hf}$ phthalocyanines with a chlorinated macrocycle, which was assigned the formula $\mathrm{ClPcMCl}_{2}$. It was later proved [31-33] that $\mathrm{ClPcMCl}$ is not an individual compound, it is a statistical mixture of chlorinated phthalocyanines with different numbers of chlorine atoms in the molecule, which corresponds to the general formula $\mathrm{ClPcMCl}_{2}$. This conclusion was confirmed by NMR spectra of bis-(acetylacetonato)phthalocyanines of $\mathrm{Zr}$ and Hf obtained from corresponding dichloride complexes described in $[29,30]$ and pure $\mathrm{PcMCl}_{2}[31-33]$. 


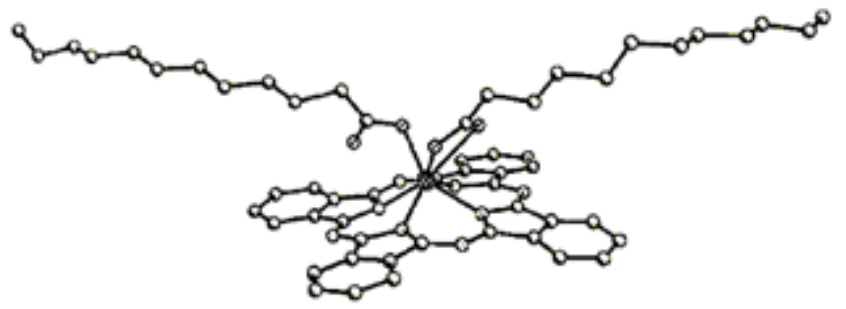

A

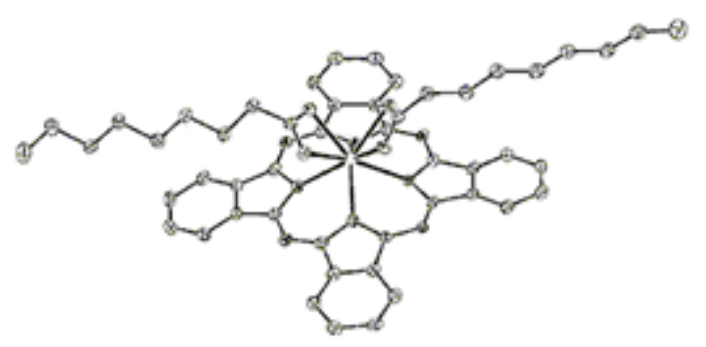

$\mathrm{C}$

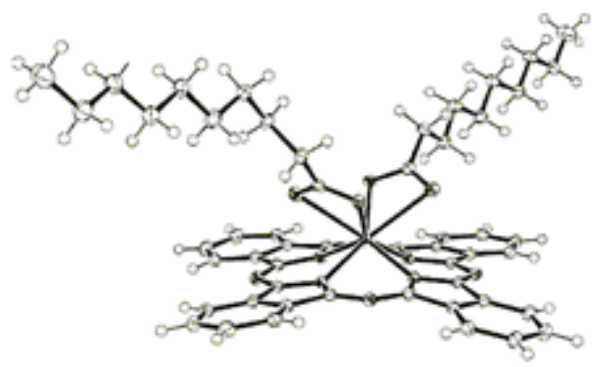

B

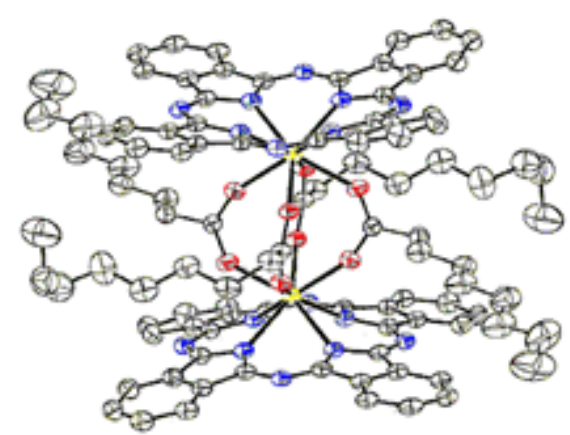

$\mathrm{D}$

Fig. 2. Crystal structure of Sn didodecanoato phthalocyaninate, $\mathrm{CN}=7$ (A) [26]; Sn didecanoato phthalocyaninate, $\mathrm{CN}=8$ (B) [27]; Hf dinonanoato phthalocyaninate, $\mathrm{CN}=8$ (C) and $\mathrm{Zr}$ bis(dinonanoato phthalocyaninate), $\mathrm{CN}=8(\mathrm{D})[28]$.

The out-of-plane chlorine atoms in $\mathrm{Zr}$ and Hf phthalocyanines are quite "mobile", they undergo hydrolysis to form corresponding dihydroxo complexes $\operatorname{PcM}(\mathrm{OH})_{2}[30,32,34,35]$. This feature was used for the synthesis of PcML $(\mathrm{L}=$ pyrocatechins $)$ and $\mathrm{PcML}_{2}(\mathrm{~L}=\beta$-dicarbonyl compounds, hydroxybenzoic, sulfo- and aliphatic carboxylic acids, etc) [28, 36-38].

The general scheme for the synthesis of out-of-plane coordinated $\mathrm{Zr}$ and Hf phthalocyanines is presented in Fig. 3. In the case of polyphenols, which are bidentate ligands, one ligand is coordinated to the CA of the macrocycle with $\mathrm{CN}=6$. If $\beta$-dicarbonyl compounds or carboxylic acids are introduced into the re- action, two ligands are coordinated [36-38] and the $\mathrm{CN}$ of the CA is 8 (Fig. 3). In this case, the carboxylic acid is a bidentate or bridging bidentate ligand [28].

According to the scheme shown in Fig. 3, out-of-plane coordinated $\mathrm{Zr}$ and Hf phthalocyanines with more complex ligands were also obtained [37, 39-44] (Fig. 4). The reactivity of out-of-plane coordinated ligands of $\mathrm{Zr}$ and Hf phthalocyanines was also investigated. It was found [37] that the "mobility" of the chlorine atom in the 3-chloro-2,4-pentanedionate ligand is very low (in contrast to free 3-chloro-2,4-pentanedione), so it does not interact with thiol-containing compounds 

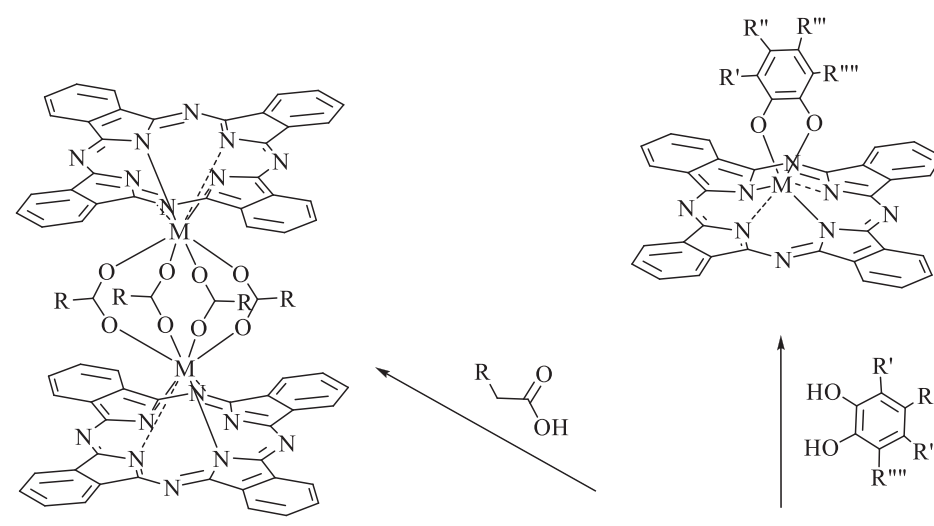

$$
\begin{aligned}
& \mathrm{R}^{\prime}=\mathrm{R}^{\prime \prime}=\mathrm{R}^{\prime \prime \prime}=\mathrm{R}^{\prime \prime \prime}=\mathrm{H} \\
& \mathrm{R}^{\prime}=\mathrm{R}^{\prime \prime}=\mathrm{R}^{\prime \prime}=\mathrm{R} " \mathrm{R}^{\prime \prime}=\mathrm{Cl} \\
& \mathrm{R}^{\prime}=\mathrm{R}^{\prime \prime \prime}=\mathrm{H}, \mathrm{R} "=\mathrm{R} \mathrm{R}^{\prime \prime}=\mathrm{Br} \\
& \mathrm{R}^{\prime}=\mathrm{OH}, \mathrm{R}^{\prime \prime}=\mathrm{H}, \mathrm{R}^{\prime \prime}=\mathrm{COOH} \text {, } \\
& \mathrm{R} " '=\mathrm{H} \\
& \begin{array}{l}
\mathrm{R}^{\prime}=\mathrm{OH}, \mathrm{R} "=\mathrm{H}, \mathrm{R} "=\mathrm{COOMe} \text {, } \\
\mathrm{R}^{\prime \prime \prime}=\mathrm{H}
\end{array}
\end{aligned}
$$

$\mathrm{R}=\mathrm{Alk}$
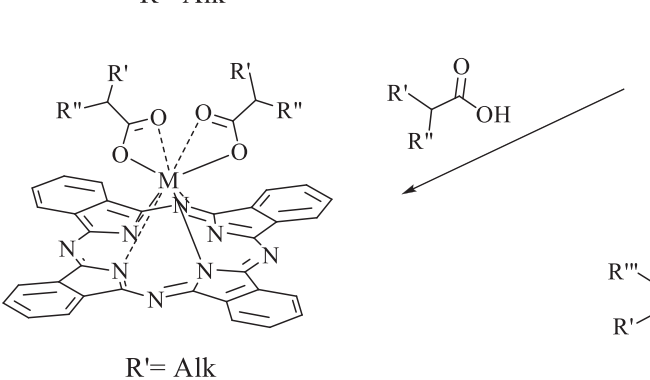

$\mathrm{R}^{\prime}=\mathrm{Alk}$

$\mathrm{R}^{\prime \prime}=\mathrm{H}, \mathrm{NH}_{2}$

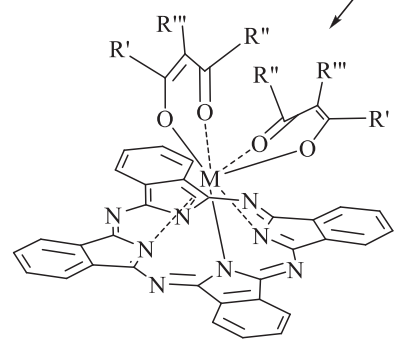

(1)

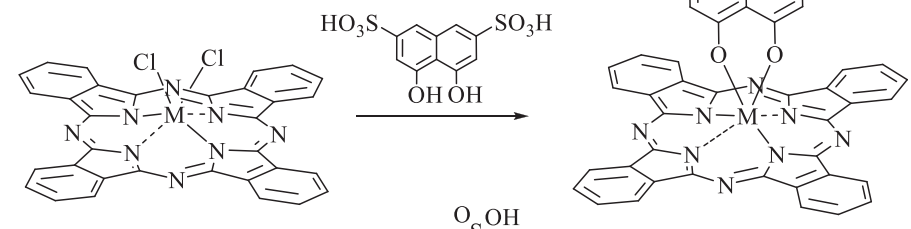

R', R", R"'=Alk, OAlk, Ar, Hal

Fig. 3. Scheme of synthesis of some out-of-plane coordinated $\mathrm{Zr}$ and $\mathrm{Hf}$ phthalocyanines.

(Fig. 5, reaction A). As a result of complexing, the phthalocyanine macroring stabilizes the formed cyclic system of the $\beta$-diketonate ligand, and the mobility of the chlorine atom sharply decreases $[28,37]$. During the reaction of the ester group, the formation of amides (Fig. 5, reaction B) was proved [28]. However, when a reaction with ammonia or hydrazine takes place, a mixture of indeterminate products is formed, or destruction of the macro- cyclic system is observed. The synthesis reaction of $\mathrm{Zr}$ and $\mathrm{Hf}$ dibromide bis-(N-(5-pentanoato)-4-methyl-pyridiniumcarboxylato) phthalocyaninates proved to be quite indicative. When dichloride complexes of $\mathrm{Zr}$ and Hf phthalocyaninates react with $\mathrm{N}$-(5-pentanoato)-4-methyl-pyridiniumcarboxylic acid bromide, a corresponding cationic complex is formed, but the anion is a mixture of chlorides and bromides (Fig. 5, reaction B). 


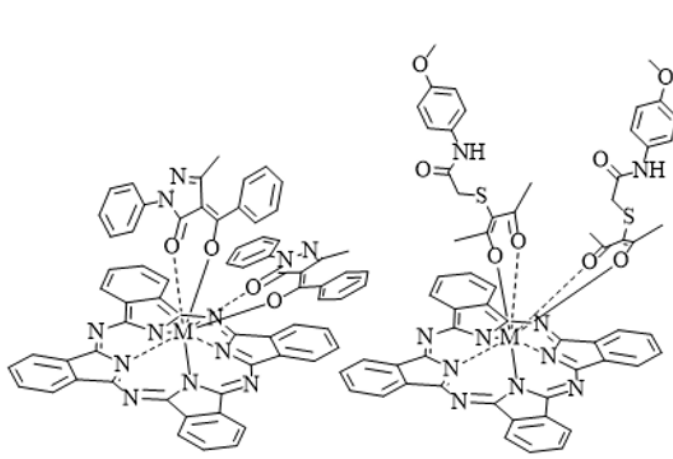

A

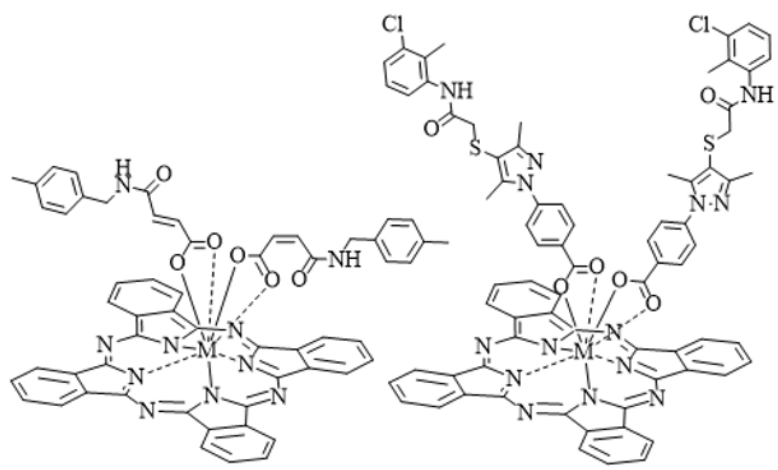

C

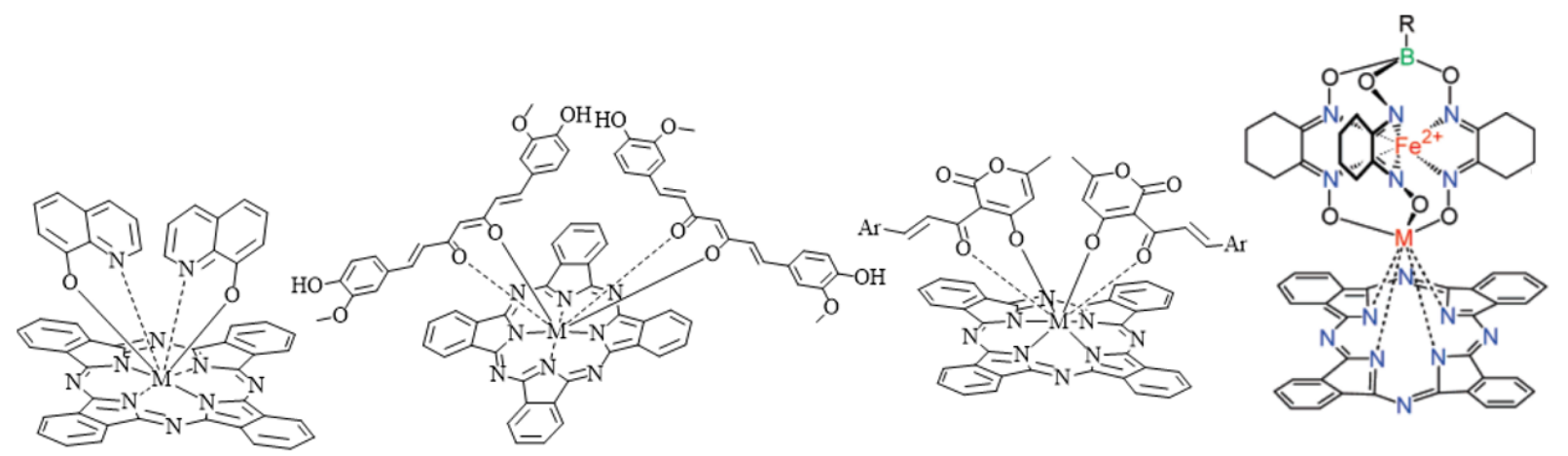

Fig. 4. Out-of-plane coordinated derivatives of $\mathrm{Zr}$ and $\mathrm{Hf}$ phthalocyanines with: 4-benzoyl-3-methyl1-phenyl-2-pyrazolin-5-onate (A) [39]; 2-(2,4-dioxopentan-3-ylthio)-N-(4-methoxyphenyl)acetamide (B) [40]; 2Z)-4-[(4-methylphenyl)-amino]-2-ovate (C) [37]; (4-[4-(\{2-[(2-methylphenyl)amino]-2-oxoethyl\}thio)-3-dimethyl-1pyrazol-1-yl]benzoic (D) [37]; oxyquinolinate (E) [ 41], curcuminate (F) [42], dehydroacetate and its condensed derivatives $(\mathrm{G})[43,44]$ as ligands, and clathrochelate $(\mathrm{H})[45]$.

If the bis- $\omega$-bromopentanoates of $\mathrm{Zr}$ and Hf phthalocyanines react with 4-methylpyridine individual cationic complexes are formed (Fig. 5, reaction D) [28, 37]. In [35], it was recommended to carry out similar reactions based on $\mathrm{Zr}$ and $\mathrm{Hf}$ dihydroxo phthalocyanines.

Structure of out-of-plane coordinated zirconium and hafnium phthalocyanines. In all out-of-plane coordinated $\mathrm{Zr}$ and Hf phthalocyanines, the ligands are located in the cis position relative to the plane of the phthalocyanine macrocycle. This arrangement of ligands has been proven by X-ray diffraction, NMR, and UV-Vis spectroscopy [36-38, 46].

According to the X-ray diffraction data of $\mathrm{Zr}$ and Hf dibenzoylmethanato phthalocyanines, the CA of the metal is out of the plane of the phthalocyanine macrocycle, which itself is not planar [46]. The central atoms are located almost in the middle between the N4 planes of the phthalocyanine macrocycle and the $\mathrm{O} 4$ of the extraplanar ligands (Table 1). 

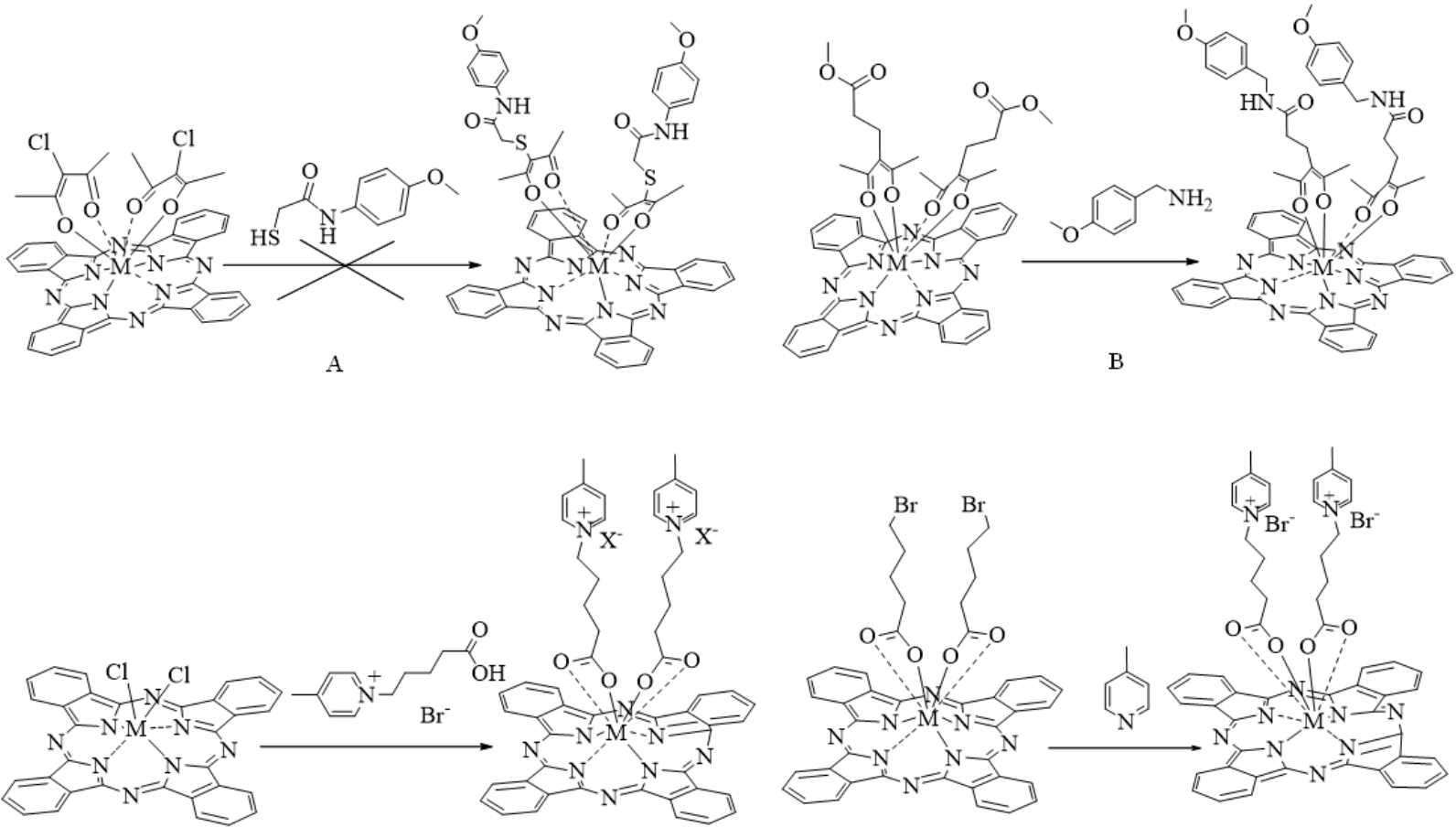

$\mathrm{X}$ - Mixture of $\mathrm{Cl}$ and $\mathrm{Br}$ anions

$\mathrm{C}$

$\mathrm{D}$

Fig. 5. Reactivity of extraplanar ligands in $\mathrm{Zr}$ and $\mathrm{Hf}$ phthalocyanines.

The similarity of the structural parameters of $\mathrm{Zr}$ and Hf bis-(dibenzoylmethanato)phthalocyanines is observed (see Table 1). This similarity exists for the very close atomic radii of $\mathrm{Zr}$ and $\mathrm{Hf}$ ions due to lanthanide compression
[47]. This leads to the similarity of both structural parameters and other spectral characteristics, such as the position of signals in NMR spectra and absorption maxima in UV-Vis spectra [46].

Table 1

\section{Selected parameters of bond lengths and distances to the planes N4 and O4 of $\mathrm{Zr}$ and $\mathrm{Hf}$ bis-(dibenzoylmethanato)phthalocyanines.}

\begin{tabular}{ccc|c|c|c}
\hline \hline Bond & Length, $\AA$ & Angle & w, degree & Distance to the plane, $\AA$ \\
\hline Zr - O & $2.1610(16)-2.1807(16)$ & O - Zr - O & $71.41-74.52$ & 1.184 \\
Hf - O & $2.1577(14)-2.1719(14)$ & O - Hf - O & $70.99-74.91$ & 1.181 \\
Zr - N & $2.282(2)-2.303(2)$ & $\mathrm{N}-\mathrm{Zr}-\mathrm{N}$ & $73.35-74.26$ & 1.211 \\
$\mathrm{Hf}-\mathrm{N}$ & $2.2641(17)-2.2919(16)$ & $\mathrm{N}-\mathrm{Hf}-\mathrm{N}$ & $73.58-74.58$ & 1.194 \\
\hline \hline
\end{tabular}


Most of the described out-of-plane coordinated $\mathrm{Zr}$ and $\mathrm{Hf}$ phthalocyanines were investigated by NMR spectroscopy. As concerns the complexes with pyrocatechinate and sulfosalicylate ligands, their solubility is too low for accurate NMR studies [36]. However, complexes of $\mathrm{Zr}$ and $\mathrm{Hf}$ phthalocyanines with $\beta$-diketones, $\beta$-ketoethers, and carboxylic acids as extraplanar ligands have been studied extensively [39, $48-50]$. In the case of $\beta$-dicarbonyl complexes, the coordination of two ligands to the CA of the macrocycle was established. Proton signals in the NMR spectra can be divided into two groups [48]. The first group is the signals of phenyl protons of the phthalocyanine macrocycle located in the region of 9.5-8.0 ppm. Their position and morphology of multiplets are similar to the data given in the literature for $\beta$-dicarbonyl phthalocyanine complexes of thorium and uranium [51]. The second group is proton signals of extraplanar ligands. They are always upfield shifted compared to uncoordinated ligands. Analysis of NMR spectre data for pairs of complexes ( $\mathrm{Zr}-\mathrm{Hf})$ with the identical ligands shows that the CA has almost no effect on the position of the signals in the spectra because they have very similar values $[36,37,46]$. In the case of complexes with asymmetric $\beta$-dicarbonyl ligands, the formation of a mixture of cis- and trans-isomers has been proved [36, 48] (Fig. 6).
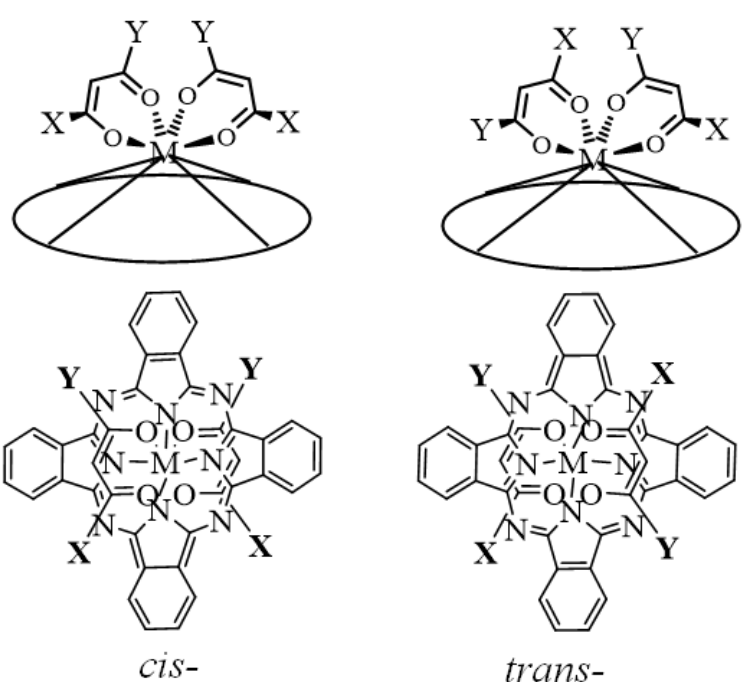

Fig. 6. Coordination of asymmetric $\beta$-diketones to the CA of the phthalocyanine macrocycle with the formation of a mixture of isomers.

Spectral characteristics. The UV-Vis spectra of out-of-plane coordinated $\mathrm{Zr}$ and $\mathrm{Hf}$ phthalocyanines in organic solvents have a typical appearance for most metal phthalocyanines, characterized by a B-band of absorption in the region of 335-350 nm, a Q-band of 680-690 nm, and its satellite in the region of 615-620 nm (Table 2) [36-38]. If the extraplanar ligand is a chromophore (e.g., curcumin or condensed derivatives of dehydroacetic acid), there are additional absorption bands in the UV-Vis spectra located between the B- and Q-bands $[38,42,44]$.

Table 2

UV-Vis data of out-of-plane coordinated $\mathrm{Zr}$ and $\mathrm{Hf}$ phthalocyanines in toluene.

\begin{tabular}{|c|c|c|c|c|}
\hline $\mathrm{M}$ & Ligand & \multicolumn{3}{|c|}{$\lambda, \operatorname{nm}(\log \varepsilon)$} \\
\hline & & B-band & Q-satellite & Q-band \\
\hline $\mathrm{Zr}$ & & $342(4.72)$ & $618(4.44)$ & $686(5.18)$ \\
\hline $\mathrm{Hf}$ & & $349(4.70)$ & $618(4.38)$ & $688(5.19)$ \\
\hline
\end{tabular}


Table 2

\begin{tabular}{|c|c|c|c|c|}
\hline M & Ligand & \multicolumn{3}{|c|}{$\lambda, \operatorname{nm}(\log \varepsilon)$} \\
\hline & & B-band & Q-satellite & Q-band \\
\hline $\mathrm{Zr}$ & & $343(4.88)$ & $617(4.54)$ & $688(5.28)$ \\
\hline Hf & & 349 (4.89) & $620(4.56)$ & $690(5.28)$ \\
\hline $\mathrm{Zr}$ & & $344.6(4.78)$ & $617.2(4.58)$ & 684.9 (5.29), $688.1(5.29) \mathrm{d}$ \\
\hline Hf & & $340.9(4.82)$ & $616.7(4.61)$ & $684.2(5.37), 686.8(5.38) \mathrm{d}$ \\
\hline $\mathrm{Zr}$ & & $340.0(5.05)$ & $617.0(4.56)$ & $656.0(4.48), 683.0(5.31) \mathrm{w}$ \\
\hline Hf & & $340.0(5.05)$ & $617.0(4.54)$ & $655.0(4.48), 683.0(5.30) \mathrm{w}$ \\
\hline $\mathrm{Zr}$ & & $336.1(4.63)$ & $618.8(4.29)$ & $685.2(5.00), 689.4(5.00) \mathrm{d}$ \\
\hline $\mathrm{Hf}$ & & $345.0(4.74)$ & $619.4(4.40)$ & $682.1(5.08), 693.3(5.09) d$ \\
\hline $\mathrm{Zr}$ & & $342.8(4.58)$ & $618.2(4.30)$ & $686.4(5.13) \mathrm{w}$ \\
\hline $\mathrm{Hf}$ & & $342.8(4.53)$ & $616.9(4.27)$ & $684.9(5.17) \mathrm{w}$ \\
\hline $\mathrm{Zr}$ & & $341.7(4.80)$ & $617.1(4.52)$ & $654.7(5.28), 685.0(5.31) \mathrm{w}$ \\
\hline $\mathrm{Hf}$ & 0 & $337.1(4.87)$ & $616.3(4.61)$ & $683.7(5.57), 685.6(5.57) \mathrm{w}$ \\
\hline $\mathrm{Zr}$ & & $341.7(4.85)$ & $618.1(4.52)$ & $686.9(5.27) \mathrm{w}$ \\
\hline $\mathrm{Hf}$ & $\begin{array}{lll}\| & \mathrm{O} & \mathrm{CH}_{3}\end{array}$ & $339.5(4.78)$ & $616.2(4.42)$ & $684.1(5.22) \mathrm{w}$ \\
\hline $\mathrm{Zr}$ & $\mathrm{CH}$ & 341 & $620 \mathrm{sh}$ & 684 \\
\hline Hf & $V_{7} 11_{15}$ & 340 & $616 \mathrm{sh}$ & 684 \\
\hline
\end{tabular}

In the case of water-soluble $\mathrm{Zr}$ and $\mathrm{Hf}$ phthalocyanines, such as sulfosalicylate, gallate, chromotropic and amino acids, absorption bands characteristic of phthalocyanine aggregates are observed in water [52].

The authors showed $[46,48,49]$ that in some cases broadening or splitting of the Q-band in the UV-Vis spectra of $\beta$-diketonate and $\beta$-ketoester complexes is observed. Such spectral characteristics are untypical of phthalocyanine complexes and associated with a significant decrease in molecule symmetry, proving the cis-coordination of the ligands relative to the plane of the phthalocyanine macrocycle.

In [50], the luminescent properties of $\mathrm{Zr}$ and Hf phthalocyanines with extraplanar ligands in various solvents were investigated. Analyzing the experimental data, the authors concluded that the heavy central metal atom reduces the fluorescence intensity of the complexes. For example, in the series $\mathrm{Zn}, \mathrm{Zr}$, Hf, the highest fluorescence is shown by zinc phthalocyanine 
(0.200 in DMSO), the quantum yield of fluorescence of $\mathrm{Zr}$ phthalocyanine is about an order of magnitude lower (Table 3), and Hf complexes do not fluoresce, or their fluorescence is very low. The highest Stokes shift is $20 \mathrm{~nm}$ which is typical of phthalocyanine complexes.

The influence of the nature of the ligands and solvents on the quantum yield of fluorescence and the lifetime of excited states in outof-plane coordinated $\mathrm{Zr}$ phthalocyanines was also established. The lowest fluorescence quantum yield was observed for $\mathrm{Zr}$ phthalocyanine dichloride (in DMSO it is 0.006), and for the complex of $\mathrm{Zr}$ phthalocyanine with 4-benzoyl3-methyl-1-phenyl-1H-pyrazole-5(4H)-one it is 0.073 (Table 3). Slightly lower quantum yields were also observed for carboxylate complexes of $\mathrm{Zr}$ phthalocyanine in comparison with $\beta$-diketonate $[39,46,49,50]$. Regarding the nature of the solvent, in toluene, the largest values of the molar extinction coefficient and the smallest values of the lifetime of the excited state were observed. At the same time, the highest values of the quantum yield of fluorescence and the lifetime of the excited state were obtained in DMSO (Table 3).

Table 3

Fluorescence data of out-of-plane coordinated $\mathrm{PcZrL}_{2}$.

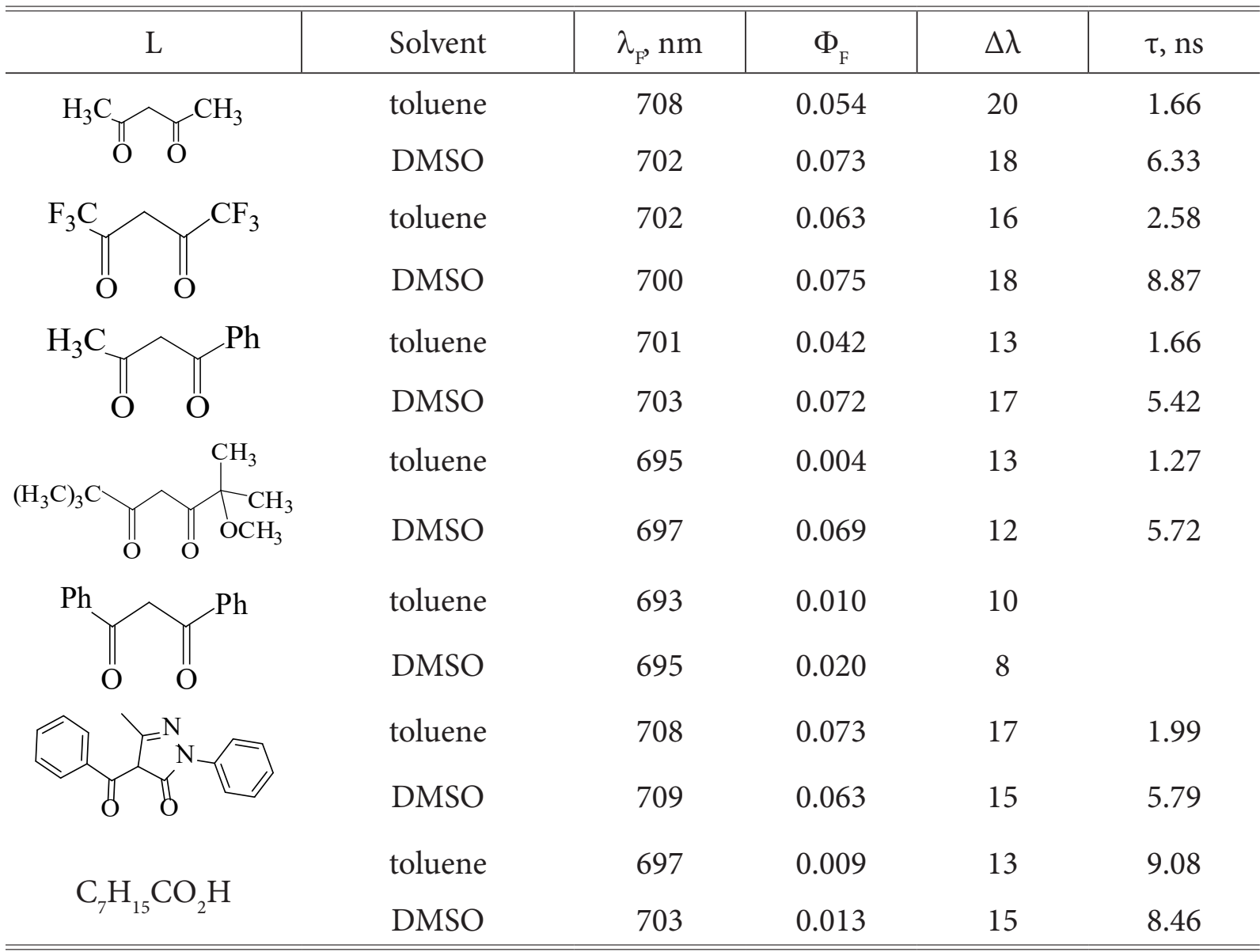


Prospects for application. Phthalocyanine complexes are widely used in many fields of science and technology [53]. The areas of their application can be divided into two groups. The first group is based on the use in a homogeneous phase, such as in photodynamic therapy, catalysis, etc. The second one is based on transformations at the phase boundary, as in sensors, photovoltaic cells, and others. Depending on the chemical nature of the extraplanar ligand, the prospects of its application are studied in different fields. $\mathrm{Zr}$ and $\mathrm{Hf}$ bis-( $\beta$-diketonato)phthalocyanines due to high electrochemical stability, fluorescence properties $[46,49,50]$, and prominent electrochromism are promising for use as sensors and the creation of photovoltaic $[40,54,55]$ and OLED elements [56-58]. Watersoluble complexes with citrate, lysinate, sulfosalicylate and other ligands show high cytostatic and cytotoxic activity and can be proposed as agents for the photodynamic and dark therapy of malignant neoplasms $[59,60]$. The complexes containing a free amino or carboxy group in extraplanar ligands show high antimicrobial activity in the composite cement with graphite oxide used in dentistry $[61,62] . \mathrm{Zr}$ and $\mathrm{Hf}$ phthalocyanines with extraplanar ligands can inhibit or redirect the fibril formation of proteins associated with neurodegenerative diseases [63-67].

CONCLUSIONS. Thus, it is shown that the coordination of out-of-plane ligands to the central metal atom in $\mathrm{Zr}$ and $\mathrm{Hf}$ phthalocyanines makes it possible to change their physicochemical properties in a targeted manner. This approach is much simpler than the in- troduction of substituents on the periphery of the phthalocyanine macrocycle. It opens up prospects for using out-of-plane coordinated $\mathrm{Zr}$ and $\mathrm{Hf}$ phthalocyanines as photosensitive, electrochromic, photoelectrocatalytic materials. Hydrophilic groups in the out-of-plane ligands provide their biological activity and the possibility of use as antitumor, antimicrobial agents.

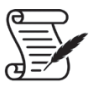

ACKNOWLEDGEMENT. This article is dedicated to our teachers, friends, and colleagues: Professor Stanislaw Radzki (1950-2008) from the Maria Curie-Skłodowska University of Lublin, Academician Serhiy Volkov (1935-2016) and Doctor of Chemical Sciences Oleg Varzatskii (1970-2017) from the V.I. Vernadsky Institute of General and Inorganic Chemistry of the National Academy of Sciences of Ukraine, Doctor of Biological Sciences Vladyslava Kovalska (1972-2020) from the Institute of Molecular Biology and Genetics of the National Academy of Sciences of Ukraine.

The work was performed within the state budget theme «Molecular design, directed synthesis, physical, biochemical study of coordination and supramolecular systems of biogenic, pharmaceutically important metals for medicine and technology», state registration number: 0121U108899 and with financial support of the NAS of Ukraine research project 0120U101275 of joint competition of projects of the NAS of Ukraine - NAS of Belarus. Also V.C. and S.C. thank Igor Siedov and his team for their help and support. 
ПОЗАПЛОЩИННО КООРДИНОВАНІ ФТАЛОЦІАНННАТИ ЦИРКОНІЮ(IV) I ГАФНЮЮ(IV)

В. Я Черній Л. А Томачинська ${ }^{1}$ Ю. С. Герасимчук ${ }^{2}$, С. В. Черній ${ }^{1}$, В. I. Пехньо

${ }^{1}$ Інститут загальної та неорганічної хімії ім. В. I. Вернадського НАН України, просп. Академіка Палладіна, 32/34, Київ 03142, Украӥна

${ }^{2}$ Iнститут низьких температур та структурних досліджень Польської Академї наук, вул. Околна 2, 50-422, Вроилав, Польща *e-mail:v.chernii@gmail.com

Статтю присвячено методам синтезу, будові та спектральним характеристикам фталоціанінатів цирконію та гафнію з позаплощинно координованими лігандами. Наведено загальну схему синтезу позаплощинно координованих фталоціанінів $\mathrm{Zr}$ та Hf. Методами РСА, ЯМР та ЕСП показано, що в усіх отриманих позаплощинно координованих фталоціанінах $\mathrm{Zr}$ i $\mathrm{Hf}$ ліганди розташовані в цис-положенні щодо площини макроциклу. Атом металу виходить із площини макроциклу фталоціаніну і розташований майже посередині між площинами N4 макроциклу фталоціаніну та О4 позаплощинних лігандів. ЕСП позаплощинно кординованих фталоціанінів $\mathrm{Zr}$ та Hf в органічних розчинниках мають типовий вигляд для фталоціанінів металів, що характеризується В-смугою поглинання в області 335-350 нм, Q-смугою 680-690 нм, та коливальним супутником при 615-620 нм. Якщо позаплощинний ліганд є хромофором (наприклад, куркумін або конденсовані похідні дегідрацетової кислоти), у ЕСП спостерігаються додаткові смуги поглинання, що знаходяться між B- та Q-смугами. Також обговорено вплив центрального атома металу, лігандів та розчинників на флуоресцентні властивості позаплощинно координованих фталоціанінів Zr та Hf.

Ключові слова: фталоціаніни, цирконій, гафній, синтез, спектроскопія.

\section{REFERENCES}

1. Braun A. Über die Produkte der Einwirkung von Acetanhydrid auf Phthalamid. Chem.Ber. 1907. 40: 2709-2713. https://doi.org/10.1002/cber.190704002202

2. Venkataraman K. Chemistry of synthetic dyes. L. GNTIHL. 1957. T. 2: 1278 (In Russian).

3. Linstead R.P. Phthalocyanines. Part I. A new type of synthetic colouring matters. J. Chem. Soc. 1934. 9: 1016-1017. https://doi.org/10.1039/JR9340001016

4. Robertson J.M. An X-Ray study of the structure of the Phthalocyanines. Part I. The metal-free, nickel, copper and platinum compounds. J. Chem. Soc. 1935. 1: 615-621.

https://doi.org/10.1039/JR9350000615

5. Bradbrook E.F., Linstead R.P. The preparation of the ten dicyanonaphthalenes and the related naphthalenedicarboxylic acids. J. Chem. Soc. 1936. 1739-1744.

https://doi.org/10.1039/JR9360001739

6. Linstead R.P., Rowe G.A. Phthalocyanines and related compounds. Part XVII. Intermediates for the preparation of tetrabenzporphins: Acids derived from phthali- 
midine. J. Chem. Soc. 1940. 1070-1076. https://doi.org/10.1039/JR9400001070

7. Barrett, P.A., Linstead, R.P., Leavitt, J.J., Rowe, G.A. Phthalocyanines and related compounds. Part XVIII. Intermediates for the preparation of tetrabenzporphins: The thorpe reaction with phthalonitrile. J. Chem. Soc. 1940. 1076-1079. https://doi.org/10.1039/JR9400001076

8. Coe D.G., Gale M.M., Linstead R.P., Timmons C.J. The cis- and trans- $\alpha \beta$-dicyanostilbenes. Part I. The geometrical configuration and cyclisation of the trans-isomer, the previously alleged diphenylmaleidinitrile. J. Chem. Soc. 1957. 123-130. https://doi.org/10.1039/JR9570000123

9. Dent C.E., Linstead R.P. Phthalocyanines. Part IV. Copper phthalocyanines. J. Chem. Soc. 1934. 1027-1031. https://doi.org/10.1039/JR9340001027

10. Linstead, R.P., Lowe, A.R. Phthalocyanines. Part V. The molecular weight of magnesium phthalocyanine. J. Chem. Soc. 1934. 1031-1033.

https://doi.org/10.1039/JR9340001031

11. Byrne G.T., Linstead R.P., Lowe A.R. Phthalocyanines. Part II. The preparation of phthalocyanine and some metallic derivatives from o-cyanobenzamide and phthalimide. J. Chem. Soc. 1934. 1017-1022. https://doi.org/10.1039/JR9340001017

12. Barrett P.A., Dent C.E., Linstead R.P. Phthalocyanines. Part VII. Phthalocyanine as a co-ordinating group. A general investigation of the metallic derivatives. J. Chem. Soc. 1936. 1719-1736. https://doi.org/10.1039/JR9360001719

13. Barrett P.A., Frye D.A., Linstead R.P. Phthalocyanines and associated compounds. Part XIV. Further investigations of metallic derivatives. J. Chem. Soc. 1938. 1157-1163. https://doi.org/10.1039/JR9380001157

14. Bradbrook E.F., Linstead R.P. Phthalocyanines. Part VIII. 1:2-Naphthalocyanines. J. Chem. Soc. 1936. 1744-1748. https://doi.org/10.1039/JR9360001744

15. Barrett P.A., Bradbrook E.F., Dent C.E., Linstead R.P. Phthalocyanines and related compounds. Part XVI. The halogenation of phthalocyanines. J. Chem. Soc. 1939. 1820-1828. https://doi.org/10.1039/JR9390001820

16. Bilton J.A., Linstead R.P. Phthalocyanines. Part X. Experiments in the pyrrole, isooxazole, pyridazine, furan, and triazole series. J. Chem. Soc. 1937. 922-929. https://doi.org/10.1039/JR9370000922

17. Cook A.H., Linstead R.P. Phthalocyanines. Part XI. The preparation of octaphenylporphyrazines from diphenylmaleinitrile. J. Chem. Soc. 1937. 929-933. https://doi.org/10.1039/JR9370000929

18. Linstead R.P., Noble E.G. Phthalocyanines. Part XII. Experiments on the preparation of tetrabenzporphyrins. J. Chem. Soc. 1937. 933-936. https://doi.org/10.1039/JR9370000933

19. Linstead R.P., Noble E.G., Wright J.M. Phthalocyanines. Part IX. Derivatives of thiophen, thionaphthen, pyridine, pyrazine, and a note on the nomenclature. J. Chem. Soc. 1937. 911-921. https://doi.org/10.1039/JR9370000911

20. Barrett P.A., Linstead R.P., Tuey G.A.P., Robertson J.M. Phthalocyanines and related compounds. Part XV. Tetrabenztriazaporphin: Its preparation from phthalonitrile and a proof of its structure. With a note on a preliminary X-ray investigation. 
J. Chem. Soc. 1939. 1809-1820.

https://doi.org/10.1039/JR9390001809

21. Barrett P.A., Linstead R.P., Rundall F.G., Tuey G.A.P. Phthalocyanines and related compounds. Part XIX. Tetrabenzporphin, tetrabenzmonazaporphin and their metallic derivatives. J. Chem. Soc. 1940. 10791092.

https://doi.org/10.1039/JR9400001079

22. Clark P.F., Elvidge J.A., Linstead R.P. Conjugated macrocycles. Part XXV. Cross-conjugated macrocycles with inner great rings of 16, 20, and 24 atoms. J. Chem. Soc. 1954. 2490-2497.

https://doi.org/10.1039/JR9540002490

23. Elvidge J.A., Golden J.H., Linstead R.P. Conjugated macrocycles. Part XXIX. Tribenzotetrazaporphin metal derivatives and dibromotribenzotetrazaporphin. J. Chem. Soc. 1957. 2466-2472.

https://doi.org/10.1039/JR9570002466

24. Kadish K.M., Smith K.M., Guilard R. Phthalocyanines: Properties and Materials. The Porphyrin Handbook. Amsterdam: Elsevier Science. 2003. 17: 289. https://doi.org/10.1016/C2009-0-22720-6

25. Berezin B.D. Coordination compounds of porphyrins and phthalocyanines. M: Science. 1978. 280 (In Russian).

26. Silver J., Frampton C. S., Fern G. R., Davies D.A., Miller J.R., Sosa-Sanchez J.L. Novel seven coordination geometry of Sn(IV): Crystal structures of phthalocyaninato bis(undecylcarboxylato)Sn(IV), its $\mathrm{Si}(\mathrm{IV})$ analogue, and phthalocyaninato Bis(chloro) silicon(IV). The electrochemistry of the $\mathrm{Si}(\mathrm{IV})$ analogue and related compounds. Inorg. Chem. 2001. 40(21): 5434-5439. https://doi.org/10.1021/ic001120a

27. Beltran H.I., Esquivel R., Sosa-Sanchez A.,
Sosa-Sánchez J.L., Höpfl H., Barba V., Farfán N., García M.G., Olivares-Xomet L.O., Zamudio-Rivera L.S. Microwave assisted stereoselective synthesis of cis-substituted TinIV phthalocyanine dicarboxylates. Application as corrosion inhibitors. Inorg. Chem. 2004. 43(12): 3555-3557. https://doi.org/10.1021/ic049634n

28. Chernii V.Ya. Synthesis, structure, properties and prospects of phthalocyanine complexes of titanium, zirconium and Hf with extraplanar ligands. Dis. Dr. Science. Kyiv. 2012. 330 (In Ukrainian).

29. Taube R. Über Titanphthalocyanine. Z. Chem. 1963. 3(5): 194.

30. Plyushchev V.E., SHklover L.P., Rozdin I.A. Sintez ftalocianinov cirkoniya i gafniya. ZH. neorg. him. 1964. 9(1): 125-127 (In Russian).

31. Pat. 38908 A, 7 C07D487/22, C07F19/00. Tomachynska L.A., Cherniy V.Ya., Volkov S.V. Method for synthesis of metallophthalocyanines from orthodinitriles and Lewis acids. - Publ. 15.05.2001, Bull. № 4 (In Ukrainian).

32. Tomachinskaya, L.A., Chernii, V.Ya., Volkov, S.V. Synthesis of dichloro phthalocyaninato complexes of titanium, zirconium, and hafnium. Zhurn. Neorgan. Khim. 2002. 47(2): 254-258 (In Russian).

33. Chernii V.Ya. Features of synthesis and ${ }^{1} \mathrm{H}$ NMR spectroscopy of phthalocyanine complexes of zirconium and hafnium. Ukr. Bioorg. Acta. 2010. 8(2). 41-46 (In Ukrainian).

34. Goedken V.L., Dessy G., Ercolani C., Fares V. Synthesis, reactivity, and X-ray crystal structure of dichloro(phthalocyaninato)titanium (IV). Inorg. Chem. 1985. 24(7): 991-995.

https://doi.org/10.1021/ic00201a006 
35. Chernii V., Tretyakova I., Selin R., Fedosova N., Kovalska V. Synthesis and Reactivity of Zirconium and Hafnium Dihydroxophthalocyaninates. Rus. J. Inorg. Chem. 2020. 65(10): 1489-1493.

https://doi.org/10.1134/S0036023620100046

36. Tomachynska L.A. Synthesis and spectroscopy of chelato-phthalocyanine complexes of titanium(IV), zirconium(IV) and hafnium(IV). Dis. Cand. Sciences. Kiev. 2002 (In Ukrainian).

37. Tretyakova I.N. Synthesis, fluorescent and electrochemical properties of phthalocyanine complexes of zinc, zirconium, hafnium. Dis. Cand. Sciences. Kiev. 2006 (In Russian).

38. Dovbii Ya.M. Synthesis, structure and properties of zirconium(IV) and hafnium(IV) with out-of-plane coordinated $\beta$-ketoenole chromophore ligands. Dis. Cand. Science. Kyiv. 2021 (In Ukrainian).

39. Tret'yakova I.N., Chernii V.Ya., Tomachinskaya L.A., Volkov S.V. Physicochemical properties of novel mixed-ligand complexes of zirconium and hafnium bis(4-benzoyl-3-methyl-1-phenyl-2-pyrazolin-5onato)phthalocyaninates. Theor. Experim. Chem. 2006. 42(3): 175-180. https://doi.org/10.1007/s11237-006-0034-3

40. Tretyakova I.M., Tomachynska L.A., Kolotilova Yu.Yu., Cherniy V.Ya. Electrochemical behavior of bis(3-substituted-2,4-pentanedionate)phthalocyanine complexes of $\mathrm{Zr}(\mathrm{IV})$ and $\mathrm{Hf}(\mathrm{IV})$ in non-aqueous media. Ukr. khim. zhurn. 2003. 69(3): 75-77 (In Ukrainian).

41. Chernii V.Ya., Tretyakova I.N., Dovbiy Ya.M., Volkov S.V. Synthesis of phthalocyanine complexes of d- and f-metals. Ukr. khim. zhurn. 2015. 81(11): 34-38 (In Russian).
42. Chernii V.Ya., Tretyakova I.N., Dovbiy Ya.M., Gorsky A.V. Zirconium and hafnium phthalocyanines with out-of-plane coordinated curcuminate ligands - synthesis and spectral properties. Ukr. khim. zhurn. 2017. 83(12): 69-75 (In Russian).

43. Cherniy V.Ya., Dovbiy Ya.M., Tretyakova I.N., Severinovskaya O.V., Volkov S.V. Synthesis and properties of phthalocyanine complexes of zirconium and hafnium with dehydroacetic acid. Ukr. khim. zhurn. 2015. 81(1): 3-7 (In Russian).

44. Dovbii Ya.M., Chernii V.Ya., Tretyakova I.M., Gorski A.V., Starukhin A.S., Volkov S.V. Synthesis of dehydroacetic acid derivatives with chromophoric chains and their complexes with zirconium phthalocyanine. Ukr. khim. zhurn. 2015. 81(12): 79-82.

45. Voloshin Y.Z., Varzatskii O.A., Korobko S.V., Chernii V.Y., Volkov S.V., Tomachynski L.A., Pehn'o V.I., Antipin M.Yu., Starikova Z.A. Ditopic macropolycyclic complexes: Synthesis of hybrid phthalocyaninoclathrochelates. Inorg. Chem. 2005. 44(4): 822-824.

https://doi.org/10.1021/ic048189t

46. Chernii V.Ya., Bon V. V., Tretyakova I.N., Severinovskaya O.V., Volkov S.V. Novel zirconium(IV) and hafnium(IV) phthalocyanines with dibenzoylmethane as outof-plane ligand: Synthesis, X-ray structure and fluorescent properties. Dyes Pigments. 2012. 94(2): 187-194.

https://doi.org/10.1016/j.dyepig.2011.12.012

47. Sheka I.A., Karlysheva K.F. Chemistry of hafnium. Kiev: Naukova dumka. 1973. 456 (In Russian).

48. Tomachynski L.A., Chernii V.Ya., Volkov S.V. Synthesis and spectral characterization 
of bis( $\beta$-diketonato)zirconium(IV) and hafnium(IV) phthalocyaninates. J. Porph. Phthalocyan. 2002. 6: 114-121.

https://doi.org/10.1142/S1088424602000154

49. Tomachynski L.A., Tretyakova I.N., Chernii V.Ya., Volkov S.V., Kowalska M., Legendziewicz J., Gerasymchuk Y.S., Radzki St. Synthesis and spectral properties of $\mathrm{Zr}(\mathrm{IV})$ and $\mathrm{Hf}(\mathrm{IV})$ phthalocyanines with $\beta$-diketonates as axial ligands. Inorg. Chim. Acta. 2008. 361(9-10): 2569-2581.

https://doi.org/10.1016/j.ica.2007.11.003

50. Tretyakova I.N., Chernii V.Ya., Tomachynski L.A., Volkov S.V. Synthesis and luminescent properties of new zirconium(IV) and hafnium(IV) phthalocyanines with various carbonic acids as out planed ligands. Dyes Pigments. 2007. 75(1): 67-72. https://doi.org/10.1016/j.dyepig.2006.05.013

51. Guilard R., Dormond A., Belkalem M., Anderson J.E., Liu Y.H., Kadish K.M. First example of 1:1 actinide-phthalocyanine complexes: synthesis, electrochemical, and spectral characterization of bis(diketonato)thorium(IV) and uranium(IV) phthalocyaninates. Inorg. Chem. 1987. 26: 14101414. https://doi.org/10.1021/ic00256a016

52. Nevin W.A., Liu W., Lever A.B.P. Dimerisation of mononuclear and binuclear cobalt phthalocyanines. Can. J. Chem. 1987. 65: 855-858.

https://doi.org/10.1139/v87-144

53. Tretyakova I.N., Cherniy V.Ya., Tomachinskaya L.A., Volkov S.V. Applied aspects of the chemistry of phthalocyanine metal complexes. Ukr. khim. zhurn. 2005. 71(1112): 85-92 (In Russian).

54. Tomachinskaya LA, Chernii V.Ya., Kolotilova Yu.Yu. Redox properties of bis-( $\beta$-dicarbonyl) phthalocyanine complexes of
zirconium(IV) and hafnium(IV). Ukr. khim. zhurn. 2002. 68(3): 64-65 (In Russian).

55. Tomachinskaya L.A., Kolotilova Y.Y., Cherni, V.Y., Volkov S.V. Electrochemical Behavior of Novel Bis( $\beta$-diketonate) phthalocyanine Complexes of $\mathrm{Zr}(\mathrm{IV})$ and Hf(IV). Theor. Experim. Chem. 2003. 39(2): 104-108.

https://doi.org/10.1023/A:1024077725675

56. Ou Zh., Zhan R., Tomachynski L.A., Chernii V.Ya., Kadish K.M. Electrochemistry and spectroelectrochemistry of zirconium(IV) and hafnium(IV) phthalocyanines with $\beta$-diketone axial ligands in nonaqueous media. Macroheterocycles. 2011. 4(3): 164-170.

57. Kolbasov G.Ya., Krasnov Yu.S., Vorobets V.S., Cherniy V.Ya., Tomachynska L.A., Tretyakova I.M., Volkov S.V. Electrochromic, electrocatalytic and photoelectrochemical properties of mixed ligand phthalocyanine complexes of zirconium and hafnium. Nauk. Visnyk Chernivtsi Univer. 2008. 401: 71-73 (In Ukrainian).

58. Krasnov Yu.S., Kolbasov G.Ya., Tretyakova I.N., Tomachynska L.A., Chernii V.Ya., Volkov S.V. Dynamics of redox processes and electrochromism of films of zirconium(IV) phthalocyanines with out-ofplane $\beta$-dicarbonyl ligands. Solid State Ionics. 2009. 180: 928-933.

https://doi.org/10.1016/j.ssi.2009.03.019

59. Tomachinskaya L.A., Gorbenko E.N., Filonenko V.V., Cherniy V.Ya., Volkov S.V. Cytotoxic antitumor activity of a new mixed ligand phthalocyanine complex of zirconium with lysine. Ukr. khim. zhurn. 2003. 69(3): 11-13 (In Russian).

60. Tomachynski L., Chernii V., Gorbenko H., 
Filonenko V., Volkov S. Synthesis, Spectral Properties, and Antitumor Activity of a New Axially Substituted Phthalocyanine Complex of Zirconium (IV) with Citric Acid. Chemistry\&Biodiversity. 2004. 1: 862-867. https://doi.org/10.1002/cbdv.200490068

61. Gerasymchuk Y., Kałas W., Arkowski J., Marciniak Ł., Hreniak D., Wysokińska E., Strządała L., Obremska M., Tomachynski L., Chernii V., Stręk W. Gallato Zirconium(IV) Phtalocyanine Complex Conjugated with $\mathrm{SiO}_{2}$ Nanocarrier as a Photoactive Drug for Photodynamic Therapy of Atheromatic Plaque. Molecules. 2021. 26: 260.

https://doi.org/10.3390/molecules 26020260

62. Gerasymchuk Y., Lukowiak A., Wedzynska A., Kedziora A., Bugla-Ploskonska G., Piatek D., Bachanek T., Chernii V., Tomachynski L., Strek W. New photosensitive nanometric graphite oxide composites as antimicrobial material with prolonged action. J. Inorg. Biochem. 2016. 159: 142-148. https://doi.org/10.1016/j.jinorgbio.2016. 02.019

63. Chernii S., Gerasymchuk Y., Losytskyy M., Szymański D., Tretyakova I., Łukowiak A., Pekhnyo V., Yarmoluk S., Chernii V., Kovalska V. Modification of insulin amyloid aggregation by $\mathrm{Zr}$ phthalocyanines functionalized with dehydroacetic acid derivatives. PLOS ONE. 2021. 16(1): e0243904. https://doi.org/10.1371/journal.pone. 0243904

64. Losytskyy M., Akbay N., Chernii S., Avcı E., Chernii V., Yarmoluk S., Culha M., Kovalska V. Characterization of the Interaction between Phthalocyanine and Amyloid Fibrils by Surface-Enhanced Raman Scattering (SERS). Analyt. Let. 2018. 51(1-2): 221-228.

https://doi.org/10.1080/00032719.2017.132 1655

65. Kovalska V., Chernii S., Cherepanov V., Losytskyy M., Chernii V., Varzatskii O., Naumovets A., Yarmoluk S. The impact of binding of macrocyclic metal complexes on amyloid fibrillization of insulin and lysozyme. J. Mol. Recognit. 2017. 30: e2622. https://doi.org/10.1002/jmr.2622

66. Kovalska V., Cherepanov V., Losytskyy M., Chernii S., Senenko A., Chernii V., Tretyakova I., Yarmoluk S., Volkov S. Anti-fibrillogenic properties of phthalocyanines: Effect of the out-of-plane ligands. Bioorg. Med. Chem. 2014. 22(240): 6918-6923. https://doi.org/10.1016/j.bmc.2014.10.024

67. Kovalska V.B., Losytskyy M.Yu., Chernii S.V., Chernii V.Ya., Tretyakova I.M., Yarmoluk S.M., Volkov S.V. Towards the anti-fibrillogenic activity of phthalocyanines with out-of-plane ligands: correlation with self-association proneness. Biopolym. Cell. 2013. 29(6): 473-479. http://dx.doi.org/10.7124/bc.00083C

Стаття надійшла 13.09.2021. 